\title{
Proiectele Erasmus+
}

\section{Cadru de dezvoltare profesională și personală a specialiștiilor în terapia tulburărilor de limbaj și de comunicare}

\author{
Raluca (SOARE) TRIFU
}

\begin{abstract}
Erasmus+ Program financed by European Union represents a real opportunity in empowering life long learning concept. Taking the opportunity for such a financial aid, 50 speech and language therapists gained theoretical and procedural knowledge in works with children with Autism Spectrum Disorder. "The Magic to communicate" coordinated by Youth Movement for Development of the Rural Areas in Bulgaria in partenership with Latvijas Logopēdu Associācija, Asociația Specialiștilor în Terapia Tulburărilor de Limbaj din România, Estonian Logopedists' Union and Lithuanian Logopedist Association, designed as a summer school, created the framework for better understanding the communication needs and language impairments in ASD. The program also represents a good change to increase professionalism of SLT and to enhance service quality in therapy with ASD.
\end{abstract}

Keywords: Erasmus+, Life Long Learning, Speech and Language Therapy (SLT)

\section{Life long learning}

Învățarea pe tot parcursul vieții este un concept cheie al politicilor europene, o stare de fapt asumată și implementată prin diferite mecanisme de finanțare ale Uniunii Europene.

„Life loong learning” reprezintă o orientare țintită, voluntară, automotivantă de a învăța, din motive personale sau profesionale (Education, Students, Formation, Papers, \& Aid, 200o). Comisia „Making a European Area of Lifelong Learning a Reality" din anul 2001 și Rezoluția Consiliului Asupra Invățării pe Tot Parcursul Vieții din 2002, au subliniat importanța acestui tip de învățare în vederea sporirii competitivității și șanselor de angajare, dar totodată și pentru incluziunea socială, cetățenie activă și dezvoltare personală. „Învățarea adulților este o componentă vitală a învățării pe tot parcursul vieții”(Commission, 2006).

Învățarea pe parcursul vieții deține pe de o parte un caracter formal, iar pe de altă parte unul informal sau non-formal.

Învățarea poate fi informală și se poate desfășura în cadrul activității profesionale printr-o serie largă de proiecte personale și profesionale, organizaționale, de dimensiuni mai mari sau mai mici. Învățarea informală are la bază concepte cheie precum „învățarea din experiență, cunoașterea implicită, transferul de învățare și practica intuitivă"(Eraut, 2004).

Învățarea formală în cazul educației continue a adulților se realizează într-un cadru organizat bine determinat, în care adulții conștientizează mult mai exact „ceea ce se învață, modul în care se învață și care sunt factorii care 
influențează direcția și efortul învățării”"(Eraut, 2004).

Indiferent de domeniul în care o persoană este activă profesional, formarea sa continuă fie la locul de muncă, fie prin proiecte complementare. Progresul profesional al fiecărui individ depinde însă de gradul său de implicare și de dorința sa de a deveni un profesionist în domeniul său de activitate.

Prin mecanismul Horizon 2020, mai exact Programul Erasmus Plus, Uniunea Europeană a creat baza legală pentru finanțarea programelor de învățare pe tot parcursul vieții, într-un cadru dinamic, dar și complex. În conformitate $\mathrm{cu}$ documentul cadru Comunicarea Comisiei din 29 iunie 2011 intitulat „Un buget pentru Europa 2020" (Parlament European \& CU Europene, 2013) se solicită crearea unui program unic în domeniul educației, formării, tineretului și sportului și al aspectelor internaționale din învățământul superior. Acest program reunește în fapt programul de acțiune din domeniul învățării pe tot parcursul vieții, denumit „Invățarea pe tot parcursul vieții", instituit prin Decizia nr. 1720/2006/CE a Parlamentului European și a Consiliului UE (Jurnal Oficial UE \& UE, 2010), precum și programele anterioare „Tineret în acțiune”, „Erasmus Mundus”, „ALFA III”, „Tempus” și „Edulink”. Scopul noului Erasmus Plus este acela de a crea un cadru de învățare care să asigure „o mai mare eficiență, o concentrare strategică mai solidă și sinergii care să fie exploatate între diferitele aspecte ale programului unic"
(Parlament European \& CU Europene, 2013).

\section{Proiecte Erasmus+ în sprijinul SLT}

Beneficiind de cadru legal "Erasmus+" Programme of the European Commission și de o finanțare venită din partea Uniunii Europene, prin intermediul "Human Resource Development Center" din Bulgaria, Youth movement for development of the rural areas in Bulgaria (www.ymdrab.eu) în parteneriat $\mathrm{cu}$ Latvijas logopēdu associācija - www.logopedi.lv, Asociatia Specialistilor în Terapia Tulburarilor de Limbaj din Romania - www.asttlr.ro, Estonian Logopedists' Union www.elu.ee și Lithuanian Logopedist Association au implementat împreună programul "The Magic to communicate". Scopul principal al acestui proiect $\mathrm{l}$-a constituit un curs de formare internațional, pe tematica comunicării la persoanele cu tulburări din spectrul autist. Programul a fost destinat specialiștilor în terapia tulburărilor de limbaj și de comunicare și s-a desfășurat în perioada 31.07.2015 to 09.08.2015 în Kranevo, Bulgaria. Prin intermediul acestui training au fost reuniți 50 de specialiști în terapia tulburărilor de limbaj și de comunciare (logopezi practicieni, proaspeți absolvenți, studenți) din Lituania, Letonia, Estonia, România și Bulgaria.

Cursurile de formare au fost tinute de traineri internaționali. Din partea ASTTLR au susținut cursuri în calitate de formatori Conf. univ. dr. Carolina Bodea Hațegan și Lector. Asociat Dr. Dorina Talaș. Activitățile au avut la bază principiile educației non-formale incluzând prezentări, grupuri de lucru 
mixte, exerciții practice, joc de rol, discuții de grup, vizite de lucru la diferite instituții specializate în asistarea persoanelor cu tulburări din spectrul autist (TSA). În cadrul activităților participanții au învățat principiile și aplicabilitatea diferitelor metode în munca cu tinerii/copii cu TSA. Au schimbat idei, și-au împărtășit experiențele proprii, au evidențiat bunele practici în abordarea persoanelor cu TSA și și-au însușit totodată abilitățile practice care să îi ajute în abordarea cu succes terapiilor de limbaj și comunicare din spectrul autist.

Beneficiu major al acestui curs îl constituie rețeaua socială și profesională creată între specialiștii logopezi din cele cinci țări menționate. Această rețea poate constitui în viitor un liant al unei eventuale colaborări profesionale în vederea îmbunătățirii calității și inovării serviciilor logopedice destinate persoanelor cu TSA. Proiectul a oferit un puternic cadru facilitator al educației și schimburilor interculturale și a ajutat la conștientizarea faptului că tulburările de comunicare din spectrul autist sunt general valabile și nu depind de limbă și cultură, în pofida particularităților lingvistice ale limbii materne. Astfel s-au creat bazele unei viitoare colaborări între organizațiile partenere ale acestui proiect.

În cadrul activităților desfășurat în proiect s-a apelat la folosirea tehnologiilor informaționale, iar formatorii au pus la dispoziție programele software și aplicațiile Android sau IOS utilizate în cadrul terapiilor logopedice cu copii cu TSA.
Dr. Plamen Dimitrov în calitatea sa de formator invitat a prezentat beneficiile utilizării analizei EEG funcțional în cazul autismului, ca metodă obiectivă și non-invazivă în vederea screening-ului timpuriu și stabilirii diagnosticului diferențial.

În aceeași idee de stabilire a unui diagnostic timpuriu, dar și a monitorizării progreselor intervenției terapeutice, Dr. Ioannis Vogindroukas, specialist în patologia limbajului și comunicării, a prezentat programul Developmental Profile of Social Communication (Vogindroukas, 2015). Programul în sine este un software care permite terapeutului să contureze un profil complet al unei persoane cu TSA, apelând la o reprezentare grafică. Profilul urmărește toate palierele de dezvoltare, punând accentul pe sociabilitate, socializare, comunicare, joc, limbaj, vorbire, scriere, abilități adaptative, reprezentare în oglindă, comunicarea non verbală, reprezentarea mentală, simbolismul, codarea limbajului, corespondența fonem grafem, etc. Prezentarea profilului ca instrument de lucru în terapia cu persoanele cu TSA a fost urmată de numeroase activități practice prin care logopezii au putut să creeze profile de dezvoltare pentru copii cu TSA, pe baza modelelor prezentate prin filmule sau a cazurilor pe care logopezii practicieni le au în terapie.

Multitudinea de resurse pe care un terapeut de limbaj le poate folosi în terapia cu copii cu TSA au fost sintetizate prin prezentarea lect. asociat dr. Dorina Talaș, iar conf. univ. dr. Carolina Bodea Hațegan a subliniat 
importanța stabilirii diagnosticului diferențiat în cazul copiilor cu TSA și a celor cu dizabilitate de auz. De multe ori copii cu dizabilitate de auz primesc inițial diagnostice greșite precum autism sau ADHD, după cum este sublimat încă de timpuriu de alte cercetări din literatura de specialitate (Capd \& Force, 1996). Iar diagnosticare lor corectă în vederea primirii de terapii logopedice specifice are o importanță aparte.

Poveștile sociale și dezvoltarea abilităților de citire sunt aspecte care trebuie incluse în terapia copiilor cu TSA, iar activitățile lectorilor din partea ASTTLR au țintit nu doar simpla prezentarea a principiilor care stau la baza terapiei, ci și exersarea utilizării lor. Grupe mixte de logopezi și-au folosit abilitățile terapeutice și creativitatea pentru a crea povești sociale, ce prezentau diferite contexte de viață reală, destinate copiilor cu TSA.

Profesor universitar Sarmīte Tūbele de la Universitatea din Latvia a încercat să răspunsă întrebării „Pot copii cu autism să citească și să scrie”. Argumentarea răspunsului a creat cadrul formal de discuții privind modul în care copii cu TSA procesează informația, privind tipologia și simptomatologia tulburării, privind preconcepțiile privitoare la TSA. Studiile de caz și filmulețele au fost utilizate ca bază de discuții.

Anna Manoleva, trainer din Bulgaria, experimentat în munca $\mathrm{cu}$ copii $\mathrm{cu}$ autism, a încercat prin prezentarea sa intitulată Development of skills for interaction and communication in children with autism, să facă cunoscută și altor logopezi abordarea sa, ca tehnică terapeutică, pentru dezvoltarea limbajului și a comunicării la acești copii. Interactiunea, comunicarea, comprehensiunea și vorbirea sunt principalii piloni și sursa unei intervenții de succes.

Fiecare informație în particular și ansamblul prezentărilor despre terapia tulburărilor de limbaj și de comunicare la persoanele $\mathrm{cu}$ TSA, în general, constituie un pachet de cunoștințe teoretice extrem de valoros. Totodată „know how-ul”, exemplele de bune practici și interculturalitatea pe care cei 50 de specialiștii în terapia tulburărilor de limbaj și de comunicare le-au experimentat și le-au însușit au creat premisele formării continue a logopezilor.

Programele europene de genul Erasmus+ reprezintă de facto posibilități de dezvoltarea personală și profesională pe care specialiștii în terapia tulburărilor de limbaj și de comunicare trebuie să le cunoască, să le promoveze și să le folosească în vederea creșterii calității serviciilor pe care ei le livrează către comunitate dar și pentru întărirea profesiei lor.

\section{Bibliografie}

Capd, A., \& Force, T. (1996). Recognizing and Treating Children with Central Auditory Processing Disorders Maxine L. Young, M. S., CCC-A / SLP, FAAA.

Commission, E. Adult learning: It is never too late to learn, COMMISSION OF THE EUROPEAN COMMUNITIES $\mathbf{1 - 1 2}$ (2006). COMMISSION OF THE EUROPEAN COMMUNITIES. 
http://doi.org/10.1080/0260137070121 9418

Education, E., Students, P. T., Formation, P., Papers, P., \& Aid, S. F. (2000). Learning for Life: White Paper on Adult Education. Document Resume, (July), 4-5.

Eraut, M. (2004). Informal learning in the workplace. Studies in Continuing Education, 26(2), 247-273. http://doi.org/10.1080/158037042000 225245

Jurnal Oficial UE, \& UE. DECIZIA NR. 1357/2008/CE A PARLAMENTULUI EUROPEAN ȘI A CONSILIULUI din 16 decembrie 2008 de modificare a Deciziei nr. 1720/2006/CE de stabilire a unui program de acțiune în domeniul învățării continue. (2010).

Parlament European, P., \& CU Europene, C. U. L 347/50. REGULAMENTUL (UE) NR. 1288/2013 AL PARLAMENTULUI EUROPEAN ȘI AL CONSILIULUI din 11 decembrie 2013 de instituire a acțiunii „Erasmus +”: Programul Uniunii pentru educație, formare, tineret și sport și de abrogare a Deciziilor nr. 1719/2006/CE, $\mathrm{nr}$ (2013).

Vogindroukas, I. (2015). Developmental Profile of Social Communication. Retrieved from http://ieel.gr/en/home/

1 Drd., Universitatea de Medicină și Farmacie „Iuliu Hațieganu” Cluj-Napoca. E-mail: Soare.Raluca@umfcluj.ro 